\title{
DETECTION AND TRANSMISSION OF RICE STUNT VIRUS ON CIHERANG AND SITU BAGENDIT VARIETIES
}

\author{
Selvi Helina', Sri Sulandari', Sedyo Hartono ${ }^{2}$, \& Andi Trisyono ${ }^{2}$ \\ ${ }^{1}$ Department of Phytopathology, Faculty of Agriculture, Gadjah Mada University, Indonesia \\ Jl. Flora No. 1 Bulaksumur Sleman Yogyakarta 55281 \\ ${ }^{2}$ Department of Plant Pests and Diseases, Faculty of Agriculture, Gadjah Mada University, Indonesia \\ Jl. Flora No. 1 Bulaksumur Sleman Yogyakarta 55281 \\ E-mail: helinaselvi@yahoo.co.id
}

\begin{abstract}
Detection and Transmission of rice stunt virus on Ciherang and Situ Bagendit Varieties. The explosion of brown planthoppers recently has caused reduction of rice production in Indonesia. Brown planthoppers do not only act as pest, but also transmit Rice grassy stunt virus (RGSV) and Rice ragged stunt virus (RRSV). Detection of the existence of the two viruses in rice plants and vector insects is important to be done to ensure that the virus is infected with the vector. The aim of this research is to detect the existence of virus in varieties of Ciherang and Situ Bagendit as a result of transmission in the laboratory and to find out the ability of brown planthoppers to transmit stunt virus to both of the varieties. This research was compiled using Completely Randomized Design (CRD) with 4 treatments, namely healthy rice plants of Ciherang and Situ Bagendit varieties, Ciherang and Situ Bagendit varieties which were infested by brown planthoppers each with 5 repetitions. The parameters observed were incubation period, symptoms, plant height, number of leaves and incidence of disease. The data on plant height, number of leaves and incidence of disease were analyzed using ANOVA and continued with the Least Significant Difference (LSD) test at the level of 5\%. The results showed that Ciherang and Situ Bagendit varieties were only positively infected by Rice ragged stunt virus. The results of the rice transmission showed that Ciherang variety had a faster incubation period of 10 DAI while Situ Bagendit was 14 DAI, but the two varieties showed an inhibition of growth in plant height and number of leaves compared to healthy plants with each incidence of $51.3 \%$ and $46.3 \%$.
\end{abstract}

Key words: Rice stunt virus, RGSV, RRSV, WBC

\section{ABSTRAK}

Deteksi dan Penularan Virus Kerdil Padi pada Varietas Ciherang dan Situ Bagendit. Ledakan wereng batang cokelat akhirakhir ini menyebabkan penurunan bagi produksi padi di Indonesia. Wereng batang cokelat tidak hanya berperan sebagai hama, tetapi dapat menularkan penyakit Rice grassy stunt virus dan Rice ragged stunt virus. Deteksi keberadaan dua virus tersebut pada tanaman padi dan serangga vektor penting dilakukan untuk memastikan virus tertular dari vektor tersebut. Penelitian ini bertujuan untuk mendeteksi keberadaan virus pada tanaman padi varietas Ciherang dan Situ Bagendit hasil penularan di laboratorium dan mengetahui kemampuan wereng batang cokelat dalam menularkan virus kerdil pada kedua varietas tersebut. Penelitian ini disusun menggunakan Rancangan Acak Lengkap (RAL) dengan 4 perlakuan yaitu tanaman padi sehat varietas Ciherang dan Situ Bagendit, tanaman padi varietas Ciherang dan Situ Bagendit yang diinfestasi wereng batang cokelat dengan masing-masing 5 ulangan. Parameter yang diamati adalah masa inkubasi, gejala, tinggi tanaman, jumlah daun dan insidensi penyakit. Data tinggi tanaman, jumlah daun dan insidensi penyakit dianalisis menggunakan ANOVA dan dilanjutkan dengan uji Least Significant Difference (LSD) pada taraf 5\%. Hasil penelitian menunjukkan bahwa tanaman padi varietas Ciherang dan Situ Bagendit hanya positif terinfeksi Rice ragged stunt virus. Hasil uji penularan tanaman padi menunjukkan bahwa varietas Ciherang memiliki masa inkubasi yang lebih cepat yaitu 10 hsi sedangkan Situ Bagendit 14 hsi, namun kedua varietas menunjukkan terjadinya penghambatan pertumbuhan tinggi tanaman dan jumlah daun dibandingkan tanaman sehat dengan insidensi masing-masing $51,3 \%$ dan $46,3 \%$.

Kata kunci: RGSV, RRSV, virus kerdil padi, WBC 


\section{INTRODUCTION}

The explosion of brown plant-hoppers (BPH or Nilaparvata lugens Stal) recently has caused a big decline in the rice production in Indonesia. The top attack of the BPH happened in the period of 2010 and 2011 which got up to $200 \mathrm{Ha}$ (Baehaki \& Mejaya, 2014). BPH are sticking and sucking insects that suck phloem vessel, decrease the chlorophyll and leaf's protein content, and also obstruct the photosynthesis rate (Watanabe \& Kitagawa, 2000). The collection of imago and nymph of BPH causes the plants to grow stunted, turn the leaves yellow, faded, and finally cause the symptom attack that is called as hopperburn (Baehaki $\&$ Mejaya, 2014). In addition, the ability of BPH which is able to adapt in many resistant varieties also becomes a very important concern. Besides of being a pest, BPH also plays role as virus disease vector, such as Rice grassy stunt virus (RGSV) and Rice ragged stunt virus (RRSV) (Hibino et al., 1985; Hibino, 1996; Toriyama et al., 1997; Chomchan et al., 2003). RRSV is a member of the family of Reoviridae genus Oryzavirus with the virus particle as icosahedral with $50 \mathrm{~mm}$ diameter (Boccardo \& Milne, 1984). RRSV particle consists of five main structural proteins which is very imunoreactive with the weight of molecule around 33, 39, 43, 70 and $120 \mathrm{kDa}$ and has five small structural protein $(49,60,76,90$, and $94 \mathrm{kDa})$ (Huihua et al., 1988). RGSV belongs to family of Bunyaviridae, Genus Tenuivirus (Hull, 2002). Particle of RSGV organized as pleomorphic, can be seen as thin filament or rounded filament and oftentimes shaped in spiral configuration (Toriyama et al., 1997).

Ditlin (2010) reported that the total attack of BPH was followed by virus infected in the period of 20012010 in Indonesia had achieved 351,748 ha which 11,354 ha of them were dried up. The virus will be multiplicity in the vector body and keep the virus inside the body even after the process of molting (change the skin) but does not inherit the virus to the next generation through eggs (Hibino, 1996; Milne \& Ling, 1982). The attack of these viruses in the field has been reported, there is even double infection recorded in the field (Suprihanto et al., 2015; Kusuma et al., 2018).

The double infection that is caused by stunt virus shows serious symptom compared to the single infection (Dini et al., 2015; Du et al., 2005). The ability of brown planthoppers infecting RGSV and RRSV has been reported (Suprihanto et al., 2015). However, up to now the report about the ability of BPH in infecting double infection simultaneously in plant has not known yet. One of the ways to know the existence of virus in the vector insect that many be done is by using PCR and infection in the rice plant (Suprihanto et al., 2015; Rahmawati et al., 2015). This method will give information about the existence of the double infection in the vector body and its ability to infect the double infection in host plant. This information will give new opinion about how far the ability of BPH in infecting RGSV and RRSV in rice plant.

\section{MATERIALS AND METHODS}

Research Site. This research was done in February to May 2018 in Virology Laboratory, Department of Plant Pests, Faculty of Agriculture, Gadjah Mada University.

Observation and Sample Rice Plant Taking. The observation and sample taking of the plant was done in the rice field when Situ Bagendit variety was two months old after planted in the vast $3225 \mathrm{~m}^{2}$ in Pleret village, Pleret Sub District, Bantul Regency, Daerah Istimewa Yogyakarta. Sample taking was done randomly with the method of sample taking diagonally. In the spread out area of the rice field was observed and taken the sample of the plant with double infection attack then was kept to be used as inoculum. Double infection was showed with the symptom of stunted plant, turned yellow in the tip of the leaf, there was none of panicles, grow upright, ragged, gall and twisted tip leaf especially in the younger part (Helina et al., 2019). Meanwhile, single infection reckon on the virus that attacked the rice plant. RGSV attack showed stunted symptom, excessive number of paddy tillers, grow upright and shorten, narrowed leaf, leaf color became pale green up to yellow and there was no panicles (Suprihanto et al., 2015). Besides of that, rice plant infected by RRSV experienced stunting, leaf color became darker with jagged edge or twisted tip, and leaf bone had swellings or lumps at the bottom of the leaf blade and the outer surface of the leaf midrib (Cabauatan et al., 2009). Before was used as inoculum, the sample was confirmed positive infected by stunt virus by using Polymerase Chain Reaction (PCR) method.

Propagation of Brown Planthoppers. BPH used was biotype 3 with instar 2. Planthopper used was planthoppers non viruliferus collection of the laboratory propagation. Propagation of planthoppers was done in a jar that closed with lint. Feed used was 2 weeks old rice plant.

Variety Test. Rice plant varieties Ciherang and Situ Bagendit were used to infection stunt virus test. Both varieties were dominantly planted by farmers in Bantul 
regency, Yogyakarta. Plants used were 10 days old after planted and kept in plastic pot with diameter $10 \mathrm{~cm}$ with plant medium consisted of soil and manure with comparison 2:1. Infection test started with planthoppers instar 2 given food (acquisition) for nine days in inoculum that was gotten in the field and then moved (inoculation) for 24 hours in the rice plant of variety test. The process of moving the planthoppers was done using aspirator. Each of plant was given 2 planthoppers per clump and then closed with plastic tube for inoculation period. After inoculated, planthoppers killed to avoid infection to the healthy rice plant.

Experimentation Plan and Statistic Analitic. This research was arranged using Completely Randomized Design (CRD) with 4 treatments and 5 repetitions. Treatment consisted of healthy rice plant varieties Ciherang and Situ Bagendit, rice plant variety Ciherang infected with $\mathrm{BPH}$, and rice plant variety Situ Bagendit infected with BPH with 5 repetition for each so that the total plant was 20 plants. Parameters observed were incubation time, symptom, disease incidence, plant's height and number of leaves. The data of plant's height, number of leaves, and disease incidence were analyzed using ANOVA and if there was any significant different, the following data was examined using Least Significant Difference test in 5\% from the significant level.

Molecular Detection of Rice Stunt Virus in Inoculum and Brown Planthoppers. Rice leaf with symptom obtained from the field, rice leaf and BPH insect infection result were used to detect the existence of rice stunt virus. Molecular detection was done through RNA total extraction, cDNA formation, cDNA amplification and DNA visualization. The RNA total extraction of the plant was done by using Total RNA mini kit (plant) and RNA extraction of the insect by using Total RNA mini kit (Tissue) with suggested procedure as in Geneaid.

Complementary-DNA (cDNA) Formation. cDNA formation was done through RT-PCR (Reverse Transcriptase-Polymerase Chain Reaction) by using First Strand cDNA Synthesis Kit ReverTra Ace with the suggested procedure as in TOYOBO. The preparation was started by preparing micro tube that had given with label then was put each $4 \mu \mathrm{L} 5 \mathrm{x}$ RT Buffer (contains $25 \mathrm{mM} \mathrm{Mg} \mathrm{2+),} 1 \mu \mathrm{L}$ ) Primer Oglio (dT) $20(10 \mathrm{pmol} / \mu \mathrm{L}), 2 \mu \mathrm{L}$ dNTP mixture $(10 \mathrm{mM}), 1$ $\mu \mathrm{L}$ ReverTra Acc, $1 \mu \mathrm{L}$ RNase Inhibitor $(10 \mathrm{U} / \mu \mathrm{L})$ and $8 \mu \mathrm{L}$ RNase-free $\mathrm{H} 20$ in the tube. After that, extraction result of RNA was put in the PCR tube as much $3 \mu \mathrm{L}$ and was homogenized by using vortex machine. The sample then was placed in the PCR machine to be done the process of RT-PCR with incubation temperature $42{ }^{\circ} \mathrm{C}$ for 20 minutes, heat 99 ${ }^{\circ} \mathrm{C}$ for 5 minutes and $4{ }^{\circ} \mathrm{C}$ for 20 minutes.

DNA Amplification and Visualization. cDNA result from RT-PCR was amplificated by using specific primer RGSV (F1:5'-GGCTTATGATAGTCTGTGATTTG-3' R: 5'GTGTAAGATGGGGTAAAGTGCA-3') which was designed by Nam et al., (2007) and RRSV (F3:5'G A C TA G G GAT G T G C G T T C - 3' / B 3 " 5 ' TGTAATCGACGTTCGCTC-3') which was designed by Le et al. (2010). Preparation was started by preparing micro tube that had given with label then was put each free water (ddH20) as much $4 \mu \mathrm{L}$, PCR mix RedMix $8 \mu \mathrm{L}$, Primer RRSV F and RRSV R with concentration 5 pmol each $2 \mu \mathrm{L}$ with template $2 \mu \mathrm{L}$, so that the total volume achieved $20 \mu \mathrm{L}$. PCR was done with initial denaturation cycle $95{ }^{\circ} \mathrm{C}$ for 1 minute, denaturation $95{ }^{\circ} \mathrm{C}$ for 15 seconds, sticking for 15 seconds, elongation $72{ }^{\circ} \mathrm{C}$ for 10 seconds and finish elongation $72{ }^{\circ} \mathrm{C}$ for 5 minutes. The PCR result product was followed by DNA visualization through electrophoresis by using agarose gel $1 \% 15 \mathrm{ml}$ TBE $1 \mathrm{x}$ and $0.15 \mathrm{~g}$ with voltage $50 \mathrm{~V}$ DC for 50 minutes. After the process of electrophoresis finished, it continued by coloring process (staining) by using Ethium bromide and visualization by using transilluuminator $U V$ and was documented with digital camera.

\section{RESULTS AND DISCUSSION}

Observation result of stunt rice symptom in the field showed that rice plant variety Situ Bagendit was suspected getting infected by two rice stunt viruses (double infection) which were Rice grassy stunt virus (RGSV) and Rice ragged stunt virus (RRSV) by showing the symptoms such as stunted plant, turned yellow in the tip of the leaf, no panicles, excessive number of paddy tillers, grow upright, ragged, gall, and twisted tip leaf (twisted) especially in the younger part (Figure 1). The symptom of double infection that found was similar with the stunt virus attacks in some other areas such as Sukamandi (Dini et al., 2015), Bali (Kusuma et $a l ., 2018$ ) and other areas in Java such as Yogyakarta, Klaten, Magelang, and Cirebon (Suprihanto et al., 2015). This double infection symptom was different with single infection where the single infection symptom was depending to the infected virus. Cabauatan et al. (2009) reported that rice plant that had infected with RGSV showed symptoms such as stunted, excessive number 
of paddy tillers, grow upright and shorten, narrowed leaf, leaf color turned to pale green up to yellow and there was no tassel produced, meanwhile rice plant that had infected RRSV became stunted, leaf color became darker with jagged edge or twisted tip, and leaf bone had swellings or lumps at the bottom of the leaf blade and the outer surface of the leaf midrib.

\section{Detection of Stunt Virus and Rice Plant Stunt Virus Infection in Ciherang and Situ Bagendit Varieties.} Based on the detection of rice inoculum sample with RT-PCR by using primer specific RGSV F1/R and RRSV F3/B3 showed result that positively infected rice stunt virus (double infection) by seeing the DNA ribbon with the size $\pm 450 \mathrm{bp}$ and $\pm 210 \mathrm{bp}$ (Figure 2 ). However, the detection of rice sample and brown planthopper of the inoculation result showed it was only infected with Rice ragged stunt virus (Figure 2 ). Rice inoculum that was infected by double infection was caused by the existence of exuberate $\mathrm{BPH}$ in the field, while the result of inoculation only used 2 planthoppers per plant. The spread of BPH in the field, moreover with the availability of stunt virus inoculum source, became the cause of spreading the virus in the field. Nevertheless, BPH was assumed to contain only one kind of virus that is RGSV or RRSV, moreover up to now there is no report about the existence of the two viruses in single vector body yet.
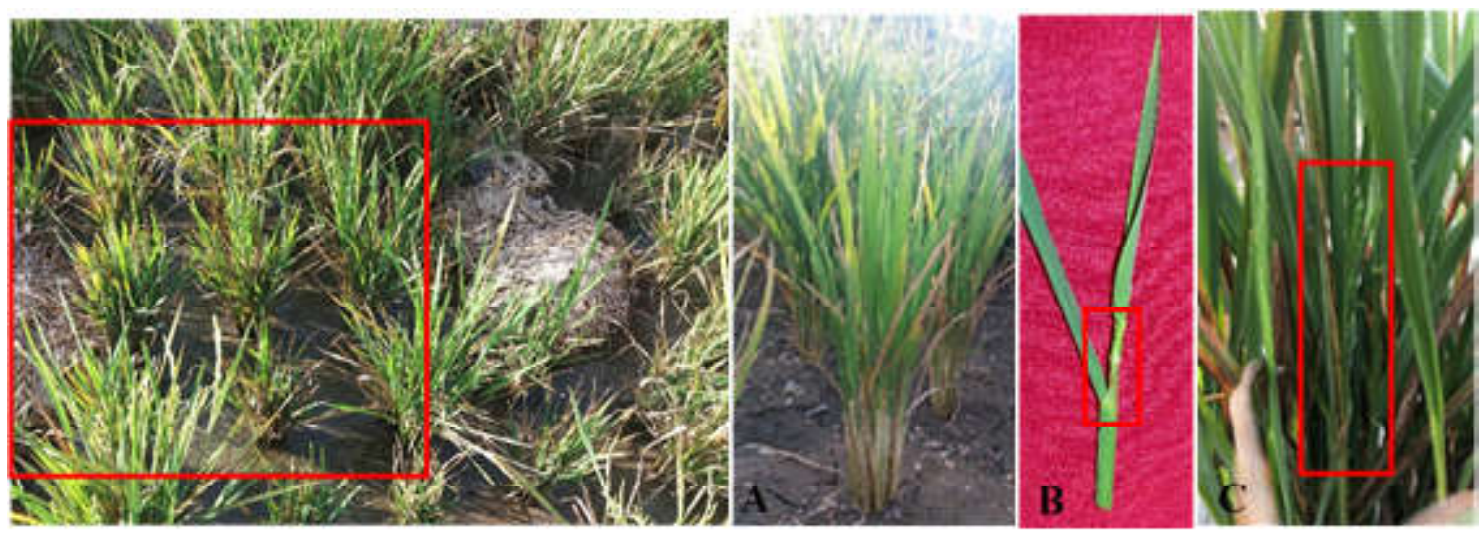

Figure 1. Stunted symptom on rice plant in Pleret village, Pleret subdistrict, Bantul regency; (A) rice plant showed stunted symptom with upright breeds, (B) gall in the base of rice stalk, (C) twisted symptom (twisted) in the base and tip of the leaf

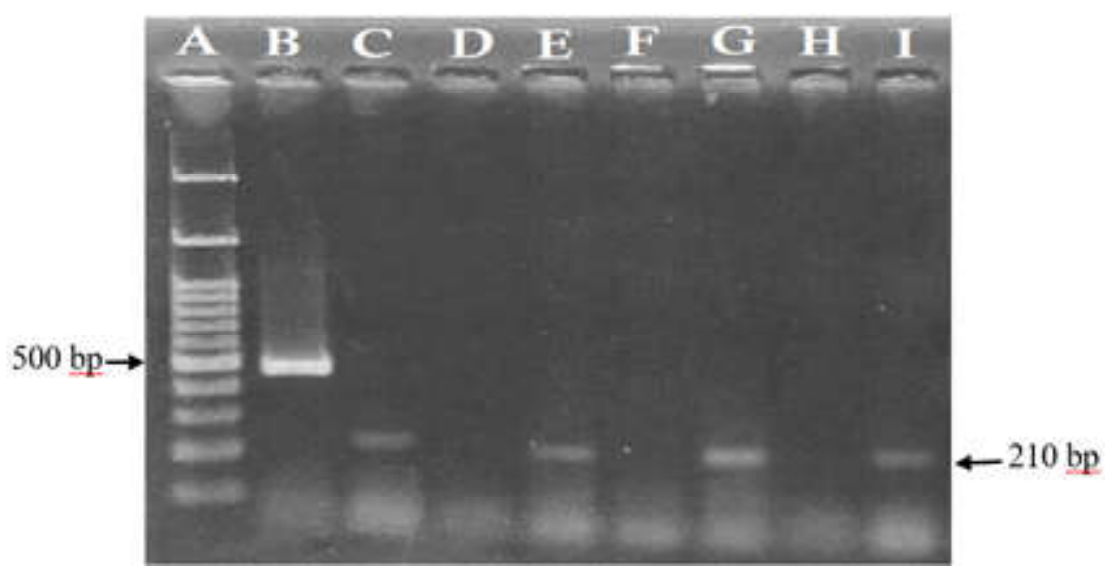

Figure 2. Visualization result RT-PCR using primer RRSV F3/B3 and RGSV F1/R in agarose gel 1,5\%. A: Marker 100 bp, B: positive control RGSV Situ Bagendit, C: positive control RRSV Situ Bagendit, D: BPH inoculation result negative RGSV, E: BPH inoculation result positive RRSV, F: Ciherang rice sample inoculation result negative RGSV, G: Ciherang rice sample inoculation positive RRSV, H: Situ Bagendit rice sample inoculation result negative RGSV, I: Situ Bagendit rice sample inoculation result positive RRSV 
RSGV was not detected in the sample of rice from inoculation and brown planthopper and it was assumed to be caused by some factors, such as the virus spreading route in the vector body, time of inoculation and host plant. Virus spreading route in the vector body was started by the entry of virus in the digestive duct and come to epithelium cell in chamber filter then anterior midgut. The virus went through basal lamina to infect muscle cell, toward saliva gland through hemolymph route (Chen et al., 2011; Zheng et al., 2014). Besides, inoculation time became one of the factors of the limitation of virus transmission in the plant. In the infection of two stunt viruses there was possibility "infection time" so that it needed inoculation period longer compared to only one virus. The longer period of inoculation, then virus contains in the vector insect was rising (Suprihanto et al., 2015). Host plant also had a role in spreading the virus. The ability of the plant was influenced by the surroundings and plant varieties so that it could limit or rise the spreading of virus in the plant.

The result of infection test showed the average of stunt disease incidence in Ciherang variety was 51.3\% and Situ Bagendit $46.3 \%$ with similar symptom response which were pale leaf color and turned yellow and also plant's height derivation and number of leaves (Figure 3). Stunt virus that attacked Ciherang variety had incubation time faster which was 10 hsi meanwhile for Situ Bagendit variety was 14 hsi (Table 1). The difference of incubation time showed the difference of

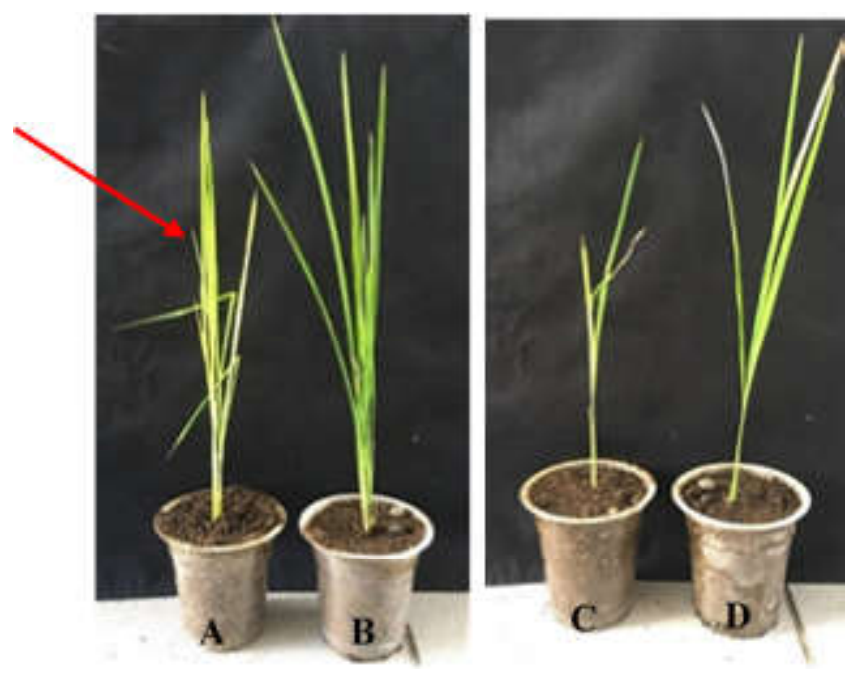

Figure 3. Symptoms of rice plant Ciherang and Situ Bagendit varieties which were 30 hsi old; (A) rice plant variety Ciherang was infected with stunt virus with symptom yellow leaf color, pale and number of leaves decreased; B Rice plant variety Ciherang was healthy; C: Rice plant variety Situ Bagendit was infected with stunt virus with symptom stunted, had pale yellow color, and few number of leaves; D: Rice plant variety Situ Bagendit was healthy

Table 1. Transmission test of stunt virus on Ciherang and Situ Bagendit varieties

\begin{tabular}{lclccc}
\hline \multicolumn{1}{c}{ Treatment } & $\begin{array}{c}\text { Incubation } \\
\text { time (DAI) }\end{array}$ & \multicolumn{1}{c}{ Symptom } & $\begin{array}{c}\text { Plant's } \\
\text { height }\end{array}$ & $\begin{array}{c}\text { Number } \\
\text { of } \\
\text { leaves }\end{array}$ & $\begin{array}{c}\text { Incidence } \\
(\%)\end{array}$ \\
\hline Ciherang without inoculation & - & No Symptoms & $32.7 \mathrm{~b}$ & $6.3 \mathrm{a}$ & $0.0 \mathrm{c}$ \\
Situ Bagendit without inoculation & - & No Symptoms & $34.0 \mathrm{a}$ & $6.2 \mathrm{a}$ & $0.0 \mathrm{c}$ \\
Ciherang with inoculation & 10 & Turned yellow and pale & $24.0 \mathrm{c}$ & $3.7 \mathrm{~b}$ & $51.3 \mathrm{a}$ \\
Situ Bagendit with inoculation & 14 & Turned yellow and pale & $24.3 \mathrm{c}$ & $3.6 \mathrm{~b}$ & $46.3 \mathrm{~b}$ \\
\hline LSD 0.05 & & & 0.89 & 2.10 & 0.21 \\
\hline
\end{tabular}

Number that are followed by different letter in the same column showed real difference based on the Least Significant Difference test with reliance level 95\%. 
interaction between the plant and the virus which will be influential to the plant response appeared. This has relation to the endurance system that owned by the plant and the level of virus virulence that infecting (Subekti et al., 2006). With the longer incubation time will make it possible for the plant to form endurance so that it will be able to hamper the virus development in the plant (Rahmawati et al., 2015).

Both Ciherang and Situ Bagendit varieties showed growth obstruction and symptom formation showing about plant's height and leaf's total that was different with healthy plant, and also rice leaf that turned yellow after inoculated stunt virus (Table 1 \& Figure 3). Virus infection caused plant metabolism system was disturbed through utilization of photosynthetic to replication and syntheses of virus particle. The effect was the plant would be lack of basic material to do vegetative growth and normal generative. Besides, stunt virus caused plant biochemist process was disturbed so that plant could not do its function well. It caused varied plant responses toward virus attack such as stunting, unproductive plant, malformation and other symptom variation (Baehaki et al., 2011).

Ciherang and Situ Bagendit are the varieties have good endurance toward brown planthopper's attack and the virus it is infected (Suprihanto et al., 2015; Rahmawati et al., 2015). However, the endurance of the varieties was broken because of brown planthopper adaptive character and the planting of the varieties continually. According to Ling (1972), high or low of attack level is depending on the susceptible of the varieties were planted, because of the ability owned by the plant to prevent infection process or limit the virus pathogen colonization. Besides, environment factor also has a role in limiting and helping the spreading of virus infection. Environment that supports the development of stunt virus will cause damage to the plant.

Virus spreading in the field is very depending to the ability of the vector in doing the transmission. Rice plant that had infected with stunt virus gave the opportunity to the vector to spread the virus moreover if the virus intensity was very high and virus attack was varied in the field. It caused possibility of brown planthoppers did not only spreading RRSV or RSGV, but double infection could happen with the availability of various inoculum sources. Generally, the symptom that appeared in the double infected plant heavier if compared to plant that was infected with each of single virus. If some viruses are infecting plant together, it will cause infection with antagonistic or synergistic character
(Hull, 2002). Synergistic infection generally happens when two viruses do not have any relation like RGSV and RRSV.

\section{CONCLUSION}

Based on the detection result with RT-PCR using specific primer RGSV F1/R and RRSV F3/B3 rice plant Ciherang and Situ Bagendit varieties and also brown planthopper were only positively infected by Rice ragged stunt virus. The result of infection test showed that Ciherang variety had incubation time $10 \mathrm{hsi}$ and Situ Bagendit had 14 hsi, both varieties showed the growth obstruction of plant's height and number of leaves compared to healthy plant with each incidence $51.3 \%$ and $46.3 \%$. Based on the inoculation result in virus infection test, brown planthopper could not infect two stunt viruses simultaneously.

\section{ACKNOWLEDGMENTS}

This document was arranged based on half of the thesis's data from first author. This research was funded by Penelitian Terapan Unggulan Perguruan Tinggi (PTUPT) grant number 1846/UN1/DITLIT/DITLIT/LT/2018.

\section{REFERENCES}

Baehaki SE, Arifin K, \& Munawar D. 2011. Peran varietas tahan dalam menurunkan populasi wereng coklat biotipe 4 pada tanaman padi. Penelitian Pertanian Tanaman Pangan. 30(3): 145-153.

Baehaki SE \& Mejaya IMJ. 2014. Wereng cokelat sebagai hama global bernilai ekonomi tinggi dan strategi pengendaliannya. Iptek Tanaman Pangan. 9(1): 1-12.

Boccardo G \& Milne RG. 1984. Plant Reovirus Group. CMI/AAB Descriptions of Plant Viruses. No. 294.

Cabauatan PQ, Cabunagan RC, \& Choi II-R. 2009. Rice viruses transmitted by the brown planthopper Nilaparvata lugens Stal. In: Heong KL \& Hardy B (Eds.). Planthopper: New Threats to the Sustainability on Intensive Rice Production Systems in Asia. pp. 357-368. International Rice Research Institute. Los Banos Philippines. 
Chen H, Chen Q, Omura T, Uehara-Ichiki T, \& Wei T. 2011. Sequential infection of Rice dwarf virus in the internal organs of its insect vector after ingestion of virus. Virus Res. 160(1-2): 389-394.

Chomchan P, Li SF, \& Shirako Y. 2003. Rice grussy stunt tenuivirus nonstructural protein $\mathrm{p} 5$ interacts with itself to form oligomeric complexes in vitro and in vivo. J. Virol. 77(1): 769-775.

Dini AFB, Winasa IW, \& Hidayat SH. 2015. Identifikasi virus penyebab penyakit kerdil pada tanaman padi di Sukamandi, Jawa Barat. J. Fitopatol. Indones. 11(6): 205-210.

[Ditlin] Direktorat Perlindungan Tanaman Pangan. 2010. Laporan Tahunan Luas dan Intensitas Serangan Hama Utama Tanaman Padi di Indonesia. Direktorat Perlindungan Tanaman Pangan, Jakarta. pp. 167.

Du PV, Cabunagan RC, \& Choi IR. 2005. Rice "yellowing syndrome" in Mekong River Delta. Omonrice. 13: 135-138.

Helina S, Sulandari S, Hartono S, \& Trisyono YA. 2019. Deteksi dan analisis profil protein tanaman padi terinfeksi virus kerdil dengan tingkat keparahan berbeda pada varietas Ciherang dan Situ Bagendit. J. Perlindungan Tanaman Indonesia. 23(1). Accepted.

Hibino H, Cabauatan PQ, Omura T, \& Tsuchizaki T. 1985. Rice grassy stunt virus strain causing tungrolike symptoms in the Philippines. Plant Dis. 69(6): 538-541.

Hibino H. 1986. Rice grassy stunt virus. Tropical Agriculture Research Series No.19. Tropical Agriculture Research Center. Ministry of Agriculture, Forestry, and Fisheries. Japan. pp. $165-172$.

Hibino H. 1996. Biology and epidemiology of rice viruses. Annu. Rev. Phytopathol. 34(1): 249-274.

Huihua L, Zuxun G, \& Tianqin C. 1988. Studies on the RNA polymerase activity associated with rice ragged stunt virus. Science in China Series BChemistry, Biological, Agricultural, Medical \& Earth Sciences. 31(5): 572-575.

Hull R. 2002. Matthews' Plant Virology, 4th edn New York: Academic Press. pp. 901.
Kusuma AF, Sulandari S, Somowiyarjo S, \& Hartono S. 2018. Molecular diversity of rice ragged stunt Oryzavirus in Java and Bali, Indonesia. Proceedings of the Pakistan Academy of Sciences: B. Life and Environmental Sciences 55(1): 57-64.

Le DT, Netsu O, Uehara-Ichiki T, Shimizu T, Choi II R, Omura T, \& Sasaya T. 2010. Moleculer detection of nine rice viruses by a reverse-transcription loop-mediated isothermal amplification assay. $J$. Virol. Methods. 70(1-2): 90-93.

Lecoq H, Desbiez C, Kheyr-Pour A, Pour-Rahim R, \& Bananej K. 2004. International Training Course on Modern Techniques for Plant Virus Diagnosis. PPDRI. Tehran. Iran.

Ling KC. 1972. Rice Virus Diseases. The International Rice Research Institute. Los Banos. Laguna. Philippines.

Milne RG \& Ling KC. 1982. Rice ragged stunt virus, In: Heong KL \& Hardy B (Eds.). Planthoppers: New Threats to the Sustainability of Intensive Rice Production Systems in Asia. pp. 904-908. The International Rice Research Institute. Los Banos. Laguna. Philippines.

Nam NT, Hung NM, Ha CH, Hang HTT, \& Binh LT. 2007. Genetic variations in Rice Grassy Stunt Virus strains isolate from Cuu Long River Delta Provinces. Tap chi cong nghe sinh hoc. 5(4): 479-484.

Rahmawati Y, Sulandari S, \& Hartono S. 2015. Respons lima varietas padi terhadap infeksi virus penyebab penyakit kerdil rumput (Rice Grassy Stunt Virus). Prosiding seminar nasional masyarakat Biodiversity Indonesia. Vol 1(5) pp. 1123-1126. Semarang, 9 Mei 2015.

Subekti D, Hidayat SH, Nurhayati E, \& Sujiprihati S. 2006. Infeksi Cucumber mosaic virus dan Chili veinal mottle virus terhadap pertumbuhan dan hasil tanaman cabai. Hayati J. Biosciences. 13(2): 53-57.

Suprihanto, Somowiyarjo S, Hartono S, \& Trisyono YA. 2015. Identification and molecular diversity of Rice ragged stunt virus and Rice grassy stunt virus in Java, Indonesia. Int. J. Sci.: Basic App. Res. (IJSBAR). 24(5): 374-386. 
Suprihanto, Somowiyarjo S, Hartono S, \& Trisyono YA. 2016. Preferensi wereng batang cokelat terhadap varietas padi dan ketahanan varietas padi terhadap virus kerdil hampa. J. Penelitian Petanian Tanaman Pangan. 35(1): 1-8.

Toriyama S, Kimishima T, \& Takahashi M. 1997. The proteins encoded by Rice grassy stunt virus RNA5 and RNA6 are only distantly related to the corresponding proteins of other members of the genus Tenuivirus. J. Gen. Virol. 78(9): 23552363.
Watanabe T \& Kitagawa H. 2000. Photosynthesis and translocation of assimilates in rice plants following phloem feeding by the planthopper Nilaparvata lugens (Homoptera: Delphacidae). J. Econ. Entomol.93(4): 1192-1198.

Zheng L, Mao Q, Xie L, \& Wei T. 2014. Infection route of Rice grassy stunt virus, a Tenuivirus in the body of its brown planthopper vector, Nilaparvata lugens (Hemiptera: Delphacidae) after ingestion of virus. Virus Res. 188: 170-173. 